\title{
REJECTION OF SOME ORIGINAL MATERIAL OF JUNCUS KOCHII (JUNCACEAE) AS USELESS FOR TYPIFICATION
}

\author{
JAROSŁAW PROĆKÓW \\ Department of Biodiversity and Plant Cover Protection \\ Institute of Plant Biology, Wrocław University \\ Kanonia 6/8, 50-328 Wrocław, Poland \\ e-mail: jprockow@biol.uni.wroc.pl
}

(Received: December 10, 2005. Accepted: February 6, 2006)

\begin{abstract}
The identity of the potential original material of Juncus kochii is discussed. The taxon at present is best regarded as Juncus bulbosus L. subsp. kochii (F.W. Schultz) Reichg. The relevant literature (protologue and references therein) was searched and details of all residual original elements were compiled. Taxonomic remarks are given. The herbarium material from the environs of Bitche (Moselle, Lorraine) and Gérardmer (Vosges, Lorraine) - both in France, has been rejected as useless for typification of $J$. kochii (because of taxonomic reasons), though it was listed both in the protologue and also as indirect references therein Schultz's earlier publications.
\end{abstract}

KEY WORDS: bulbous rush, Juncaceae, Juncus bulbosus, Juncus bulbosus subsp. kochii, Juncus kochii, original material, taxonomy.

\section{INTRODUCTION}

The paper forms a part of the 'Juncus bulbosus Synonyms Typification Project' (e.g., Proćków 2002, 2006a, b), aimed at clarifying the complicated nomenclature (synonymy) within this extremely variable taxon (because of the high morphological diversity of the bulbous rush, there exists about 60 synonyms). Juncus kochii F.W. Schultz was lectotypified recently (Proćków 2006a) and at present is best regarded as Juncus bulbosus L. subsp. kochii (F.W. Schultz) Reichg. - see e.g., Casper and Krausch (1980). The discussion on the extant potential original material is introduced here. Thus the relevant literature (protologue and references therein) was searched and details of all residual original elements were compiled. Namely Schultz in the protologue of Juncus kochii (1855) additionally cites the following references to his earlier publications:

(1) 'J. supinus $\delta$ nigritellus F. S. in Flora bot. Zeit. 1840, p. 640', and

(2) 'Fl. d. Pfalz' [Schultz 1846]. In the last bibliographic position (Schultz 1846: 480) other, subsequent new references are given:

(3) 'F. S. Arch. de la Fl. pag. 62',

(4) 'Fl. G. et G. exs., add. au 56 de la 4e Cent.', and

(5) 'Juncus nigritellus Koch, F. S. Fl. G. et G. exs. 356'.
Additional original material examined - specimens from the environs of Bitche (Moselle, Lorraine) and Gérardmer (Vosges, Lorraine) - both in France:

A) Marais de sphagnum dans les bois des montagnes, de grès vosgien, à Bitche. 28 Jun. 1839, Fl. Gall. \& Germ. Exsicc. $-4^{\mathrm{e}}$ cent., rec. F. G. Schultz, No. 56 (C!; L $106359 \mathrm{ex}$ Herb. Weiss No. 24 \& Herb. W. D. J. Koch!; L ${ }^{\text {II }} 106340$ !; L ${ }^{\text {III }}$ 106339 ex Herb. Schultes! - top left part of the sheet; HAL 86174!; FI 185285 ex Herb. Webbianum, photo! - right hand specimen; NCY ex Herb. Soyer-Villemet, photo!; G 13210 ex Herb. de Candolle!; GII 13211 ex Herb. Delessert! - top part of the sheet; PI 403943 ex Herb. Grenier!; PII 494152 ex Herb. Cosson! - top left part of the sheet) - Juncus supinus Moench [C -2 plants, $\mathrm{L}^{\mathrm{I}}-4, \mathrm{~L}^{\mathrm{II}}-1, \mathrm{~L}^{\mathrm{III}}-1, \mathrm{HAL}-1, \mathrm{FI}-1$, $\left.\mathrm{NCY}-1, \mathrm{G}^{\mathrm{I}}-1, \mathrm{G}^{\mathrm{II}}-1, \mathrm{P}^{\mathrm{I}}-1, \mathrm{P}^{\mathrm{II}}-1\right]$;

B) Côte des bois des montagnes de grès vosgien, sur la terre nue et humide, à Bitche. 11 Jul. 1839, Fl. Gall. \& Germ. Exsicc. $-4^{\mathrm{e}}$ cent., rec. F. G. Schultz, No. 56 bis (C!; M 10226!; BR ex Herb. Jean Callé!; HAL 86176!; L 106339 ex Herb. Schultes! - top right part of the sheet; B! - top part of the sheet; NCY, photo!; GI 13211 ex Herb. Delessert! - bottom part of the sheet; G ${ }^{\mathrm{II}} 13212$ ex Herb. de Candolle!; PI 403942 ex Herb. Grenier!; PII 494153 ex Herb. Cosson! - bottom right part of the sheet) - Juncus supinus $[\mathrm{C}-3$ plants, $\mathrm{M}-1, \mathrm{BR}-6$, $\mathrm{HAL}-2, \mathrm{~L}-1, \mathrm{~B}-1, \mathrm{NCY}-1, \mathrm{G}^{\mathrm{I}}-1, \mathrm{G}^{\mathrm{II}}-5, \mathrm{P}^{\mathrm{I}}-1$; $\left.\mathrm{P}^{\mathrm{II}}-1\right]$;

C) Endroits humides, bords des fossés, des sources, etc., parmi les mousses, les sphagnum, etc., sur les côtes et au pied 


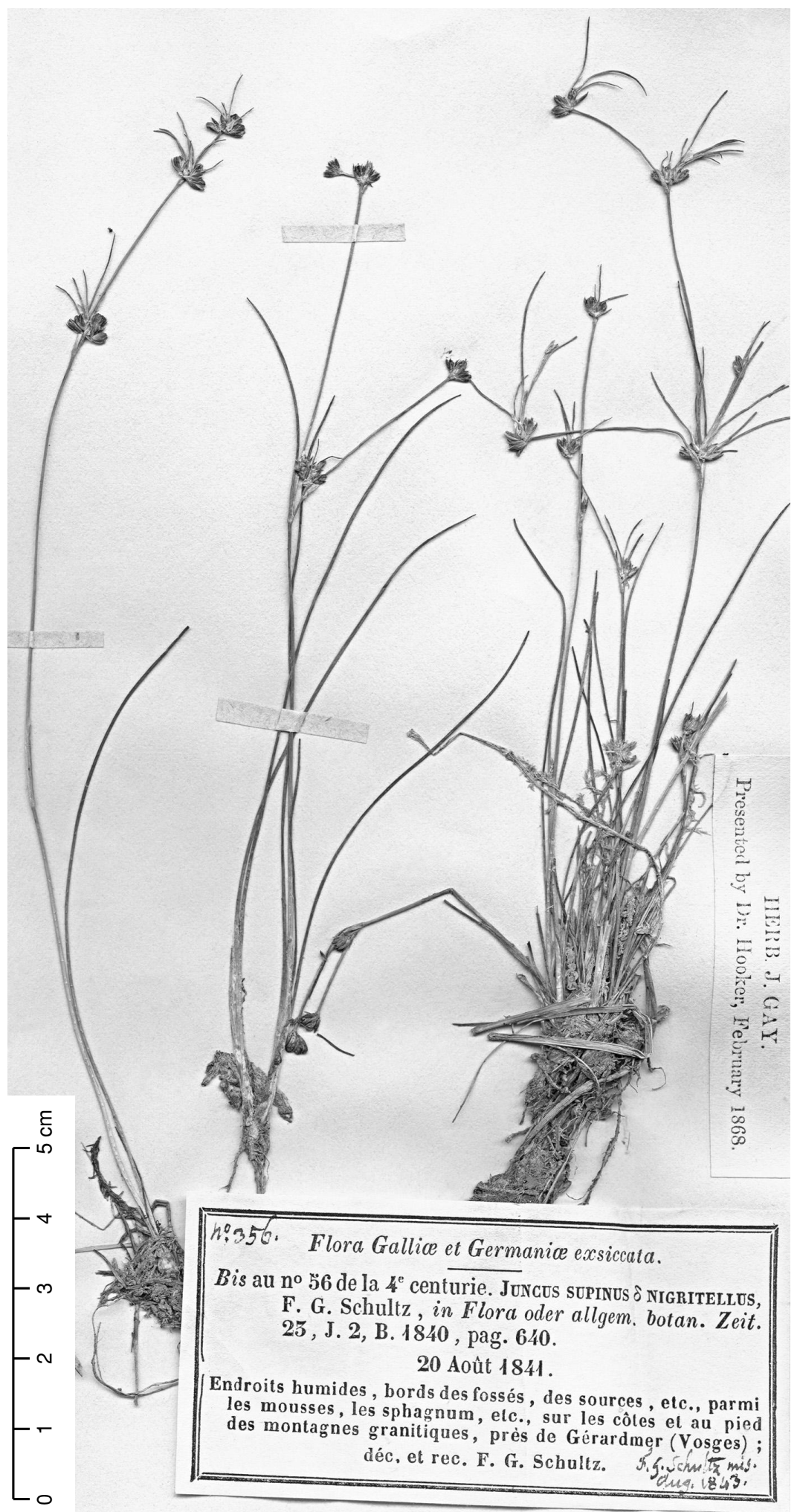

Fig. 1. A part of "potential original" Schultz's material of Juncus kochii (K ex Herb. J. Gay! - author's phot.). The middle plant only belongs to Juncus bulbosus subsp. kochii indeed. Both residual plants belong to Juncus bulbosus subsp. bulbosus as generally understood at present. For comparative characters, based on the protologue, between Juncus bulbosus subsp. kochii and subsp. bulbosus see Table 1 in Proćków 2006a. des montagnes granitiques, près de Gérardmer. 20 Aug. 1841, Fl. Gall. \& Germ. Exsicc. - Bis au n ${ }^{\circ} 56$ de la $4^{\mathrm{e}}$ cent., F.G. Schultz, No. 56 bis (L $\mathrm{L}^{\mathrm{I}} 106419$ !; L ${ }^{\mathrm{II}} 106431$ ex Herb. W. D. J. Koch!; HAL 86175!; K ex Herb. J. Gay! - top right part of the sheet (Fig. 1); B! - bottom part of the sheet; NCY, photo!; P 494148 ex Herb. Grenier!) - Juncus supinus $\delta$ nigritellus F.G. Schultz $\left[\mathrm{L}^{\mathrm{I}}-2\right.$ plants, $\mathrm{L}^{\mathrm{II}}-5, \mathrm{HAL}-3, \mathrm{~K}-3, \mathrm{~B}-2$, $\mathrm{NCY}-2, \mathrm{P}-2]$; 
Juncus bulbosus L., Sp. Pl.: 327. 1 May 1753.

[Lectotype (designated by Snogerup (1985: 20); specified by Proćków (2002: 551)): Herb. Linn. No. 449.27, right-hand specimen (LINN)].

subsp. kochii (F.W. Schultz) Reichg. in S. J. van Ooststroom \& al., Fl. Neerl. 1(6): 189 (1964) $\equiv$ Juncus kochii F.W. Schultz, Jahresber. Pollichia 13: 32 (1855) $\equiv$ Juncus supinus var. kochii (F.W. Schultz) Syme, Engl. Bot., ed. 3B(10): 33 (1870) $\equiv$ Juncus supinus subsp. kochii (F.W. Schultz) Nyman, Consp. Fl. Eur. 748 (1882) $\equiv$ Juncus supinus race kochii Rouy, Fl. France 13: 244 (1912) $\equiv$ Juncus supinus Moench var. nigritellus W.D.J. Koch, Syn. Fl. Germ. Helv., ed. 2(2): 843 (1844), nom. illeg. [non (D. Don) F.W. Schultz, 1840].

Lectotype (designated by Proćków (2006a: 790)): [Rhineland-Palatinate, SW Germany] "Auf Ihrem Standorte beim Stüderhof von H.[errn] Böhmer gesammelt und mir mitgetheilt" [Schultz's handwriting]. Jul 1838, "Juncus nigritellus”, Böhmer/Schultz? (Herb. W.D.J. Koch, L 106429!).

In Schultz's note (1840) the following locality is stated: "im Torfmoore zu Bitsch" - 'Bitsch' should be treated as a German spelling of the French name Bitche in Moselle, Lorraine, since actually the village 'Bitsch' is located ca. $310 \mathrm{~km}$ south, in Valais Canton, W Switzerland. But it is also important that Schultz (1855) states that near Bitsch he found intermediate forms between Juncus kochii and $J$. bulbosus, which had flowers with 4, 5 and 6 stamens. Based on the diagnosis of $J$. kochii, Schultz associated these specimens with Juncus bulbosus (and thus clearly excluded them from Juncus kochii). Also in his exsiccates (No. 56 and No. 56 bis) he determined them as Juncus supinus Moench. The specimens are actually Juncus bulbosus L., and - based on the diagnosis - they mostly do not represent subsp. kochii except the right-hand specimen on No. 56 from C and left-hand specimen on L 106359 (the last one has got the green perianth - compare Proćków 2006a and his subsequent papers). In view of these data, though Bitche is in fact located in the "sandstone" part of the Vosges (and this is the part that is mentioned in the protologue as the first locality), exsiccates No. 56 and No. 56 bis cannot in this case be regarded as original material of Juncus kochii. Consequently, the reference to 'J. supinus $\delta$ nigritellus F.S. in Flora bot. Zeit. 1840, p. 640' (with the locality 'im Torfmoore zu Bitsch", Flora Galliae et Germaniae exsiccata - III \& IV Centurie, but with no sheet number) cannot be regarded as an indirect reference to one of the elements of a new taxon, too. And it is also important that Schultz then (1840: 640) validly published a new varietal name $J$. supinus var. nigritellus (D. Don) F.W. Schultz, 1840, i.e. a new combination based on D. Don's name (now recognized as a synonym of Juncus articulatus L. subsp. articulatus), though erroneously applied to Koch's taxon (cf. Art. 7.4 of the Code: Greuter et al., 2000 and see also Proćków 2006a)!

An analogous information on finding intermediate forms between Juncus kochii and J. bulbosus (as above) was given by Schultz (1855) in reference to localities in the granite part of the Vosges in France. However, analysis of herbarium material from Gérardmer, Lorraine (Bis au n ${ }^{\circ} 56$ de la 4 e cent.) with respect to the diagnosis of Juncus ko- chii showed that the collection of $J$. bulbosus was actually a mixture (though the plants were not "intermediate"!), with only the following specimens representing subsp. kochii: L 106419 (both plants), L 106431 (all plants except the middle one), HAL 86175 (left-hand specimen only), K (middle plant only - Fig. 1) and P 494148 (left-hand specimen only, with the green perianth - compare Proćków 2006a and his subsequent papers). However these plants (though the set was collected as "Juncus supinus $\delta$ nigritellus") cannot be recognized as original material of J. kochii, because Schultz (1855) clearly stated that the specimens were not typical but "intermediate", as he believed, and thus might not reflect well his concept of Juncus kochii.

Besides, the last Schultz's (1846) citation in 'Flora der Pfalz' ('F. S. Fl. G. et G. exs. 356') should be regarded as a typographic error, since Exs. No. 356 of 4th Cent. pertains to Callitriche hamulata Kütz $\beta$. homoiophylla (see Schultz 1842-1854) - it should be: 'exs. 56'. But this reference (as it is Bitche locality, see above) cannot also be accepted as an indirect reference to one of the elements of a new taxon. In turn the rest of analyzed references (see Introduction) is not in disagreement with the protologue and original collections.

Based on the analyses, Schultz's herbarium material from the environs of Bitche and Gérardmer has been rejected as useless for typification of $J$. kochii because of taxonomic reasons, though it was listed both in the protologue and also as indirect references therein Schultz's earlier publications!

\section{ACKNOWLEDGEMENTS}

I am grateful to the herbarium curators who searched through their collections on my behalf or who sent the specimens for this research: AAU, B, BM, BP, BR, BUC, C, DAO, E, ER, FI, G, GB, GDOR, GH, GOET, HAL, JE, K, KSC, L, LIV, LZ, M, NCY, NMW, OUPR, OXF, P, POLL, RB, S, VT, W, WAG, WB, WRSL. I thank Dr Stefan Dressler (FR) for information which proved useful when searching for Schultz's Herbarium, Prof. Jacques Lambinon (LG) and Dr Gaëtan Guignard (LY) for their help when deciphering abbreviations on French herbarium labels and Prof. Gérard G. Aymonin (P) for material which served as a basis to correct typographical errors in Schultz's publications. The visit to the collections and libraries of Muséum National d'Histoire Naturelle, Paris, was supported by the European Commission's (FP 6) Integrated Infrastructure Initiative grant SYNTHESYS (FR-TAF). I am grateful to Prof. Gérard G. Aymonin, Dr Marc Pignal, and Cécil Aupic for their help during my study at P. I thank my boss Prof. dr hab. Jadwiga Anioł-Kwiatkowska, for her support and encouragement.

\section{LITERATURE CITED}

CASPER S.J., KRAUSCH H.-D. 1980. Pteridophyta und Anthophyta. Lycopodiaceae bis Orchidaceae. In: Süßwasserflora von Mitteleuropa. Pascher A. (ed.). VEB Gustav Fischer Verlag, Jena, Vol. 23(1), pp. 1-403. 
GREUTER W., McNEILL J., BARRIE F.R., BURDET H.-M., DEMOULIN V., FILGUEIRAS T.S., NICOLSON D.H., SILVA P.C., SKOG J.E., TREHANE P., TURLAND N.J., HAWKSWORTH D.L. (eds) 2000. International Code of Botanical Nomenclature (Saint Louis Code) adopted by the Sixteenth International Botanical Congress, St. Louis, Missouri, July-August 1999. Regnum Vegetabile 138. Koeltz, Scientific Books, Königstein.

PROĆKÓW J. 2002. A more precise lectotypification of Juncus bulbosus L. (Juncaceae). Taxon 51(3): 551-552.

PROĆKÓW J. 2006a. Lectotypification of Juncus kochii and Juncus supinus var. nigritellus (Juncaceae). Taxon 55(3): 788-790.

PROĆKÓW J. 2006b. Nomenclatural notes on Juncus welwitschii (Juncaceae). Annales Botanici Fennici 43(4): 307-309.

SCHULTZ F.W. 1840. [Note in:] Flora oder allgemeine botanische Zeitung 23(2/40): 640.

SCHULTZ F.W. 1842-1854. Archives de la flore de France et d'Allemagne. Bitche, Haguenau, Deux-Ponts.

SCHULTZ F.W. 1846. Flora der Pfalz: enthaltend ein Verzeichnis aller bis jetzt in der bayerischen Pfalz und den angränzen- den Gegenden Badens, Hessens, Oldenburgs, Rheinpreussens und Frankreichs beobachteten Gefäßpflanzen, mit Angaben der Dauer und der Blüthezeit, aller bis jetzt bekannt gewordenen Fundorte und Finder, der Natur der Fundorte und der geognostischen Beschaffenheit des Bodens, mit Merkmalen neuer und zweifelhafter Arten und anderen Bemerkungen, nach Kochs Synopsis und Taschenbuch der deutschen und Schweizer Flora geordnet, und nebst Beifügung der Anordnung der Gattungen nach dem Linneischen Sexualsysteme, der tabellarischen Uebersicht der Ordnungen des natürlichen Systems, sowie der Gattungs- und Artenmerkmale, im Auszuge aus diesen Werken. G.L. Lang, Speyer.

SCHULTZ F.W. 1855. Standorte und Verbreitung der Juncaceen und Cyperaceen in der Pfalz. Jahresbericht der Pollichia, eines naturwissenschaftlichen Vereins der Rheinpfalz 13: 30-54.

SNOGERUP S. 1985. Juncaceae. In: Flora of Turkey and the East Aegean Islands. Davis P.H., Mill R.R. and Tan K. Edinburgh, Vol. 9, pp. 1-32. 